Canadian Studies in Population, Vol. 31(1), 2004, pp. 15-31

\title{
Contraceptive Sterilization among Canadians, 1984-1995
}

\author{
Vijaya Krishnan \\ University of Botswana \\ Gaborone, Botswana, Africa \\ Kelly Martin \\ University of Victoria \\ Victoria, British Columbia, Canada
}

\begin{abstract}
Prior to early 1970s, traditional methods were the principal means of controlling the number and spacing of births. Today, an estimated 57 per cent of the world's married women use contraceptives and half use modern methods such as medical sterilizations. Recent statistics suggest that Canada has the highest sterilization rate in the Western world. This paper presents findings of research examining sterilization trends in Canada with respect to changing patterns in the use of modern contraceptives, using data from the 1984 Canadian Fertility Survey (CFS) and the 1995 General Social Survey (GSS). The main finding is that there is a decrease in the use of tubal ligation and an increase in the use of hysterectomy over the period 1984-1995. Less educated women are more likely to be in the forefront of modern methods of contraception.
\end{abstract}

Key Words: Contraception, sterilization, 1984 Canadian Fertility Survey, hysterectomy, tubal ligation, General Social Survey 
Vijaya Krishnan and Kelly Martin

\section{Résumé}

Avant les années 1970, les méthodes traditionnelles représentaient le principal moyen de contrôler et d'espacer le nombre de naissances. De nos jours, on estime que 57 pour cent des femmes mariées dans le monde entier utilisent un moyen contraceptif et la moitié utilise des méthodes modernes telles que la stérilisation. Les dernières statistiques indiquent que le Canada compte le taux de stérilisations le plus élevé dans le monde occidental. Cet article présente les conclusions de recherches portant sur les tendances en matière de stérilisation au Canada en ce qui concerne les modèles changeants d'utilisation de moyens de contraception modernes et ce, à partir de données de l'Enquête canadienne sur la fécondité de 1984 et de l'Enquête sociale générale (ESG) de 1995. La principale conclusion qui en est ressortie est une réduction de la ligature des trompes et une augmentation du nombre d'hystérectomies de 1984 à 1995. Les femmes moins éduquées sont plus portées à se trouver au premier plan des méthodes de contraception modernes.

Mots-clés : contraception, stérilisation, Enquête canadienne sur la fécondité de 1984, hystérectomie, ligature des trompes, Enquête sociale générale

\section{Introduction}

Throughout Western society, the multiple socio-cultural transformations of recent decades have brought a complex set of shifts in demographic circumstances. All developed regions, including North America have experienced improvements in socioeconomic conditions, low marriage and fertility rates, and contraceptive revolution. Women's higher educational levels and increased labor force participation, especially since the 1950s brought greater opportunities for women by reducing their economic dependence on men. It also led to a revolution in birth control by allowing them to choose if and when to become pregnant. The demographic transition in North America has been so dramatic, as Preston (1984) observed, "an earthquake had shuddered through the American family” (see, Skolnick \& Skolnick, 1999, p. 301).

The decline in fertility has been one of the most remarkable demographic realities in modern times in Canada. In 1999, the total fertility rate in Canada hit a record low of 1.52 children per woman (Statistics Canada, 2002). Fertility rates are falling for a number of reasons. Declining marriage rates, rising divorce rates, delaying the birth of the first child, and the changing status and roles of women all continue to affect fertility levels to drop. However, the key factor appears to be the use of more effective contraceptive methods. Prior to the 1970 s, traditional methods (e.g., withdrawal, rhythm, douching) were the principal means of controlling the number and also the spacing of births. However, the use of traditional methods has not resulted in significant fertility 
declines. It was only after the introduction of more effective modern contraceptive methods and induced abortion, marked declines in fertility started to take place. Although estimates of the abortion rate before legalization in 1969 were as high as $14 \%$ of live births (McLaren and McLaren, 1986), abortion as such did not contribute significantly to the decline of fertility in North America because it is more often used by women who are unmarried or divorced, who have never had a child or have only one, and who are in their twenties (Nett, 1993). In other words, it was mostly used as a last option in the case of unwanted pregnancies.

The rapid popularization of such modern contraceptive methods as the hormonal pill, intra-uterine devices, spermicidal gels and foams, condoms, and sterilizations, makes it hard to rule out that the family is hit by a medical "earthquake." In Canada, among women aged 15 to 19 who use contraceptives, $86 \%$ use a pharmaceutical method, primarily the pill, and $14 \%$ use a barrier method, mainly the condom (Statistics Canada, 2002). By 1995, some 3.3 million couples had undergone a vasectomy or tubal ligation to stop having children (Belanger, 1998). Of the $56.1 \%$ of married women $18-49$ years of age who chose sterilization as their method of contraception, $30.0 \%$ had a tubal ligation and the remaining were relying upon their husbands' vasectomies (Belanger, 1998).

This situation suggests the growing popularity of contraceptive sterilization in Canada. Similar developments are experienced elsewhere in the West, particularly in the United States. Data from the 1991 National Survey of Men in the United States indicated that about $12 \%$ of married men aged 20-39 have had a vasectomy and about $13 \%$ had a wife who was sterilized (Forste, Tanfer, \& Tedrow, 1995).

How do the countries of the West behave with regard to sterilization? It is difficult to make international comparisons of the prevalence rate of sterilization, for several reasons. First, nationwide data on sterilization are scarce. Second, the availability of data varied from country to country; in some cases, data sources are quite outdated. Finally, existing data for each country make it difficult to compare because of differences in sampling and methodology.

Globally, sterilization has become a leading method of choice in regulating fertility among women of childbearing ages (Gentile, Kaufman, \& Helbig, 1998). As Belanger (1998) reported, compared with other western countries, voluntary sterilization for contraceptive purposes is remarkably widespread in Canada. Mauldin \& Segal's (1988) study of the prevalence of contraceptive use indicated that the three leaders in the world in terms of sterilization were Puerto Rico, Canada, and South Korea with more than $40 \%$ of couples in the reproductive ages have been sterilized. A survey in 1984 and 1985 of 7696 women aged 15-44 living in Italy, France, Great Britain, Spain, and West 
Vijaya Krishnan and Kelly Martin

Germany (Riphagen \& Lehert, 1989) revealed that sterilization was more frequent in Great Britain (23\%) than in the other four countries (Italy, 1\%; France, 5\%; Spain, 3\%; and Germany, 7\%). According to Riphagen and Lehert, sterilization was not legal in Italy and rarely practiced in Spain and it was slightly more frequent among women with a lower level of education in other countries. As the authors noted, sterilization evoked some doubt about health safety in France, Germany, and Spain and a slightly greater degree in Italy, but not in Great Britain. In Great Britain, either oral contraceptives, the IUD, or sterilization was considered unsafe. In the 1970s and 1980s, there was concern about vasectomy and atherosclerosis after a report of an increased risk of atherosclerosis among those who had undergone the procedure (Peterson \& Howards, 1998).

According to the United Nations (1999), female sterilization predominates in the less developed regions, while the pill is the most popular method in the more developed regions. Worldwide, about 155 million relied on male or female sterilization in the late 1980s (Mauldin \& Segal, 1988) with about 19 million found in the developed countries.

While there is a compelling body of research to suggest the importance of opening our eyes to the sterilization 'syndrome' (e.g., Poma, 1980; Shy, Stergachis, Grothaus, Wagner, Hecht, \& Anderson, 1992), the demographic and physiological consequences of sterilization require much more thinking and research. It is within this context that contraceptive sterilization is examined here. The paper examines sterilization trends in Canada with respect to changing patterns in the use of modern irreversible procedures such as hysterectomies. Data on sterilization from the 1984 Canadian Fertility Survey and the 1995 General Social Survey are compared to indicate trends and patterns of use of irreversible methods of contraception among Canadian women.

\section{Methods}

\section{Data}

Data for the study came from the 1984 Canadian Fertility Survey (CFS) and the 1995 General Social Survey (GSS). The CFS was Canada's first and only national fertility survey, using telephone interviews for both household selection and in-depth interviewing of the selected respondents, namely, women in the reproductive ages of 18 to 49 years. A total of 5,315 women of all marital statuses who were interviewed constituted a nationally representative sample.

The CFS questionnaire was an outgrowth of not only the World Fertility Survey questionnaire, but also other surveys done in Canada ( e.g., Family 
History Survey, 1984) and the United States ( e.g., National Survey of Fertility Growth, 1973, 1976, 1982) (Krotki, 1988). It contained a substantial number of questions on childbearing intentions and experiences, contraceptive behavior, and abortion. It also covered a range of topics, including pregnancy, marriage, and work histories and socioeconomic variables, such as income, education, and religion (where applicable, socioeconomic data were also obtained on the husband).

The 1995 GSS was the $10^{\text {th }}$ Cycle of the General Social Survey, using telephone interviews, conducted by Statistics Canada. The Survey was based on a national probability sample of 5,914 women and 4,835 men 15 years of age and older. It contained information on marital and reproductive histories, childbearing intentions, contraceptive practices, and socioeconomic characteristics of respondents and their partners. The respondents in the GSS did not match those in the CFS, in terms of age. However, the GSS provided a unique opportunity to study Canadian men's contraceptive behavior for the first time.

Unlike the CFS, the GSS was not intended to gather data about fertility. Its focus was mainly on the family. Further, it provided less information than the CFS about contraceptive use. For example, the CFS respondents were asked for multiple method use whereas the GSS included only questions on which method the respondents were currently using.

In both the CFS and the GSS, respondents were asked to indicate what method(s) of contraception they and their partners were using; they were given a number of different methods to choose from. The GSS distinguished between those who had the operation for contraceptive purposes, medical reasons, or both. Needless to say, hysterectomies, to some extent, are due to medical problems. That is, they are done for medical or contraceptive reasons. In order to make meaningful comparisons between the two surveys, it was felt necessary to separate those who were medically sterile from those who were sterile due to contraceptive reasons. Thus, in the GSS, those who reported that they themselves or their partners had operations for contraceptive or both reasons were considered contraceptively sterile (tubal ligation or vasectomy). Those who reported operations for medical reasons were considered medically sterile.

For the present study, in order to make the samples comparable, the sample from the GSS was restricted to include only those women aged 18 to 49 years. This procedure reduced the sample size to 3,220 women in the GSS, including nonusers of contraception. 
Vijaya Krishnan and Kelly Martin

\section{Results}

The reader is reminded that we are concerned exclusively with the question on contraception that the respondents or their partners were currently using. The sample of respondents was broken down into users of two forms of irreversible procedures of contraception, namely, hysterectomy and vasectomy. The numbers and percentages of women's report of their use of tubal ligations and hysterectomies and their husbands' or partners' use of vasectomy in the two national surveys are presented in Table 1. To understand the extent of contraceptive use, in general, data on reversible methods are also presented. Also included in the Table are numbers and percentages of those who had undergone sterilization for medical reasons.

Table 1

Trends in Contraceptive Use by Women and their Husbands/Partners across Two National Surveys for Canada: 1984 and 1995

\begin{tabular}{|c|c|c|c|c|c|c|}
\hline \multirow{3}{*}{ Method } & \multirow{2}{*}{\multicolumn{2}{|c|}{$\frac{\text { CFS } 1984}{\text { Women }}$}} & \multicolumn{4}{|c|}{ GSS 1995} \\
\hline & & & \multicolumn{2}{|c|}{ Women } & \multicolumn{2}{|c|}{ Men } \\
\hline & number & percent & number & percent & number & percent \\
\hline Reversible $^{\mathrm{a}}$ & 1889 & 35.6 & 1033 & 32.1 & 1211 & 34.8 \\
\hline Irreversible & 1977 & 39.9 & 1304 & 40.4 & 1073 & 31.1 \\
\hline Tubal Ligation & 1285 & 24.2 & 559 & 17.3 & $355^{*}$ & $10.6^{*}$ \\
\hline Vasectomy & $462 * *$ & $8.7 * *$ & $343 * *$ & $10.6 * *$ & 453 & 13.1 \\
\hline Medical Sterilization ${ }^{\mathrm{b}}$ & 230 & 7.0 & 402 & 12.5 & 265 & 7.7 \\
\hline Pregnant & 200 & 3.8 & 78 & 2.4 & 138 & 4.0 \\
\hline Non-Users & 1107 & 20.8 & 807 & 25.1 & 1027 & 29.8 \\
\hline TOTAL & 5315 & 100.0 & 3222 & 100.0 & 3449 & 100.0 \\
\hline
\end{tabular}

a Includes pill, condom, IUD, diaphragm, foam, rhythm, withdrawal, douche (in CFS) and sponge (in GSS).

$B$ Includes those who were naturally or surgically sterile.

* The figures are based on men's report of their wives'/partners' method use.

** The figures are based on women's report of their husbands'/partners' method use.

Source: Canadian Fertility Survey, 1984; General Social Survey, 1995. 
In $1984,19 \%$ of women reported using the pill and $6 \%$ reported having had their husbands/partners using the condom (not shown). By contrast, in 1995, nearly $17 \%$ had used the pill and almost $10 \%$ had their husbands/partners used the condom. The male sample indicated as many as $22 \%$ using a condom with $9 \%$ of their wives/partners using the pill in 1995 (not shown).

Tubal ligation was the most common reported form of sterilization in 1984 . Comparisons between 1984 and 1995 figures indicate an increase in vasectomy and sterilization for medical reasons and a decrease in tubal ligations (Table 1). The decision to terminate childbearing and consequently the decision to favor a particular method of contraception may be affected by a host of factors, including sociodemographic, emotional, and values of both the spouses (Miller, Shain, \& Pasta, 1989; Goldberg \& Toros, 1994). Goldberg and Toros (1994), for example, found fears of adverse health effects as given by $10 \%$ of women who preferred tubal ligation when asked why they were not using a method they preferred. Many researchers investigated the premenstrual symptoms and menstrual disturbances of post-tubal sterilization and recommended hysterectomy instead of tubal ligation (e.g., Gentile, Kaufman, \& Helbig, 1998; Shy et al., 1992; Wilcox, Chu, Eaker, Zeger, \& Peterson, 1991; Wilcox, Martinez-Schnell, Peterson, Ware, \& Hughes, 1992). Thus, the lower incidence of tubal ligation in 1995 is attributable in part to the fact that there was more awareness among women of the risks associated with the procedure. However, more research on the relationship between factors affecting contraceptive use and sterilization decision is needed before a firm conclusion can be made.

To further explore shifts in contraceptive use, several variables from both the CFS and GSS were examined: age, marital status, education, number of children, religion, religious attendance, and province or region of residence. The results are presented in Tables $2 \mathrm{a}$ through $3 \mathrm{c}$. Among the CFS respondents, use of tubal ligation ranged from $56.7 \%$ in the $18-24$ year age group to $68.4 \%$ in the 35-39 year age group (Table 2a).

Examination of age reveals that the practice of tubal ligation and age was an inverted U-shaped distribution in 1984. Goldberg and Toros (1994) observed a similar trend among Turkish couples using modern methods and an U-shaped relationship between traditional methods and age.

The GSS data support the recent trend that tubal ligation has become a less popular contraceptive choice in Canadian women of all ages. However, recent evidence indicates to an increasing popularity of tubal ligation in women aged 45 years and older. By 1995, the inverted U-shaped distribution relating age and tubal ligation had almost disappeared.

Among both the CFS and GSS survey respondents, formerly married women had the highest rate of tubal ligation use compared to their married or unmarried 
Vijaya Krishnan and Kelly Martin

Table 2a

Number and Percentages of Tubal Ligations by Selected SocioDemographic Characteristics of Women Age 18-49 Years in Two National Surveys for Canada: 1984 and 1995

\begin{tabular}{|c|c|c|c|c|c|c|}
\hline \multirow[b]{2}{*}{ Method } & \multicolumn{3}{|c|}{ CFS 1984} & \multicolumn{3}{|c|}{ GSS 1995} \\
\hline & $\begin{array}{c}\text { number of } \\
\text { women }\end{array}$ & $\begin{array}{l}\text { tubal li } \\
\text { number }\end{array}$ & $\begin{array}{l}\text { ations } \\
\text { percent }\end{array}$ & $\begin{array}{c}\text { number of } \\
\text { women }\end{array}$ & $\begin{array}{l}\text { tubal } 1 \\
\text { number }\end{array}$ & $\begin{array}{l}\text { ations } \\
\text { percent }\end{array}$ \\
\hline \multicolumn{7}{|l|}{ Age Group } \\
\hline $18-24$ & 30 & 17 & 56.7 & 21 & 3 & 14.3 \\
\hline $25-29$ & 169 & 110 & 65.1 & 73 & 24 & 32.9 \\
\hline $30-34$ & 376 & 246 & 65.4 & 192 & 68 & 35.4 \\
\hline $35-39$ & 525 & 359 & 68.4 & 314 & 147 & 46.8 \\
\hline $40-44$ & 472 & 300 & 63.6 & 366 & 153 & 41.8 \\
\hline $\begin{array}{l}45-49 \\
\text { Marital Status }\end{array}$ & 406 & 254 & 62.6 & 337 & 164 & 48.7 \\
\hline Married & 1595 & 1002 & 62.8 & 973 & 394 & 40.5 \\
\hline Cohabiting & 117 & 79 & 67.5 & 125 & 46 & 36.8 \\
\hline Formerly Married & 223 & 179 & 80.3 & 149 & 95 & 63.8 \\
\hline $\begin{array}{l}\text { Unmarried } \\
\text { Education }\end{array}$ & 43 & 25 & 58.1 & 56 & 24 & 42.9 \\
\hline Elementary & 869 & 585 & 67.3 & 291 & 145 & 49.8 \\
\hline High School & 531 & 333 & 62.7 & 322 & 145 & 45.0 \\
\hline $\begin{array}{l}\text { Some College or } \\
\text { University }\end{array}$ & 577 & 367 & 63.6 & 692 & 269 & 38.9 \\
\hline Number of Child & & & & & & \\
\hline None & 113 & 46 & 40.7 & 93 & 16 & 17.2 \\
\hline One & 184 & 118 & 64.1 & 142 & 47 & 33.1 \\
\hline Two or More & 1680 & 1121 & 66.7 & 1069 & 496 & 46.4 \\
\hline
\end{tabular}

Sources: Canadian Fertility Survey, 1985 and General Social Survey, 1995. 
counterparts (Table 2a). The percentages of women using tubal ligation in 1984 were nearly constant with education, at around 63 to $67 \%$. However, educational differences in tubal ligation were more pronounced in 1995. On the whole, women with more children opted for tubal ligation compared to their counterparts who were childless. In general, the procedure appears to be more popular among older and formerly married women.

As the data in Table $2 \mathrm{~b}$ indicate, there is an inverse relationship between women's age and their spouses' use of vasectomy with about $62 \%$ of users had their wives/partners in the age group 25-34 in 1984. By 1995, the relationship between women's age and the proportion of men using vasectomy became an inverted U-shaped distribution.

The GSS revealed significant differences in spouses' vasectomy use by women's education; nearly $32 \%$ of women who had some college or university education reported having had their husbands/partners using vasectomy compared with $13 \%$ of women who had less than a secondary level of education having had their husbands/partners using vasectomy.

In 1984, there existed no significant differences in the use of vasectomy in terms of the number of children a couple had. By 1995, proportionately more men with two or more children opted for vasectomy than those with one child or no children at all.

The age-specific data revealed that by 1995, hysterectomy remained the contraceptive method of choice for younger Canadian women. For instance, $71 \%$ of those aged $18-24$ and $40 \%$ of those aged $25-29$ had hysterectomies in 1995 (Table 2c). It is clear, then that hysterectomies are predominantly used by young women during the early years of their reproductive life.

Apparently, unmarried were more likely to be the users of hysterectomies in both the surveys; the rate of use in 1995 was more than double the rate for 1984. Perhaps the most striking finding is that, in both 1984 and 1995, hysterectomies were mostly used by women with less than a secondary school education; the percentage using hysterectomies increased from 13.7 in 1984 to 37.1 in 1995 (Table 2c). This finding is similar to that of Riphagen and Lehert (1989) in Europe. The authors reported that sterilization was slightly more frequent among women with a lower level of education in France, Germany, and Great Britain.

In $1984,33.6 \%$ of women with no children opted for hysterectomies, and in 1995 , the proportion increased to $67.7 \%$ (Table 2c). Even among those with two or more children, the increase in the use of hysterectomies more than doubled. 
Vijaya Krishnan and Kelly Martin

Table 2B

Number and Percentages of Partners' Vasectomies by Selected SocioDemographic Characteristics of Women Age 18-49 Years in Two National Surveys for Canada: 1984 and 1995

\begin{tabular}{|c|c|c|c|c|c|c|}
\hline \multirow[b]{2}{*}{ Method } & \multicolumn{3}{|c|}{ CFS 1984} & \multicolumn{3}{|c|}{ GSS 1995} \\
\hline & $\begin{array}{c}\text { number of } \\
\text { women }\end{array}$ & $\begin{array}{r}\text { vasec } \\
\text { number }\end{array}$ & $\begin{array}{l}\text { mies } \\
\text { percent }\end{array}$ & $\begin{array}{c}\text { number of } \\
\text { women }\end{array}$ & $\begin{array}{r}\text { vase } \\
\text { number }\end{array}$ & $\begin{array}{l}\text { mies } \\
\text { percent }\end{array}$ \\
\hline \multicolumn{7}{|l|}{ Age Group } \\
\hline $18-24$ & 30 & 11 & 36.7 & 21 & 3 & 14.3 \\
\hline $25-29$ & 169 & 52 & 30.8 & 73 & 20 & 27.4 \\
\hline $30-34$ & 376 & 116 & 30.9 & 192 & 78 & 40.6 \\
\hline $35-39$ & 525 & 118 & 22.5 & 314 & 92 & 29.3 \\
\hline $40-44$ & 472 & 106 & 22.5 & 366 & 91 & 24.9 \\
\hline $45-49$ & 406 & 58 & 14.3 & 337 & 58 & 17.2 \\
\hline \multicolumn{7}{|l|}{ Marital Status } \\
\hline Married & 1595 & 422 & 26.5 & 973 & 315 & 32.4 \\
\hline Cohabiting & 117 & 22 & 18.8 & 125 & 27 & 21.6 \\
\hline Formerly Married & 223 & 12 & 5.4 & 149 & 0 & 0.0 \\
\hline Unmarried & 43 & 6 & 14.0 & 56 & 0 & 0.0 \\
\hline \multicolumn{7}{|l|}{ Education } \\
\hline Elementary & 869 & 165 & 19 & 291 & 38 & 13.1 \\
\hline High School & 531 & 147 & 27.7 & 322 & 85 & 26.4 \\
\hline $\begin{array}{l}\text { Some College or } \\
\text { University }\end{array}$ & 577 & 150 & 26 & 692 & 220 & 31.8 \\
\hline \multicolumn{7}{|c|}{ Number of Children } \\
\hline None & 113 & 29 & 25.7 & 93 & 14 & 15.1 \\
\hline One & 184 & 40 & 21.7 & 142 & 23 & 16.2 \\
\hline Two or More & 1680 & 211 & 23.4 & 1069 & 176 & 28.6 \\
\hline
\end{tabular}

Sources: Canadian Fertility Survey, 1985 and General Social Survey, 1995. 
Contraceptive Sterilization among Canadians, 1984-1995

Table 2C

Number and Percentages of Hysterectomies by Selected Socio-Demographic Characteristics of Women Age 18-49 Years in

Two National Surveys for Canada: 1984 and 1995

\begin{tabular}{|c|c|c|c|c|c|c|}
\hline \multirow[b]{2}{*}{ Method } & \multicolumn{3}{|c|}{ CFS 1984} & \multicolumn{3}{|c|}{ GSS 1995} \\
\hline & $\begin{array}{c}\text { number of } \\
\text { women }\end{array}$ & $\begin{array}{r}\text { hyster } \\
\text { number }\end{array}$ & $\begin{array}{l}\text { tomies } \\
\text { percent }\end{array}$ & $\begin{array}{c}\text { number of } \\
\text { women }\end{array}$ & $\begin{array}{l}\text { hyster } \\
\text { number }\end{array}$ & $\begin{array}{l}\text { tomies } \\
\text { percent }\end{array}$ \\
\hline Age Group & & & & & & \\
\hline $18-24$ & 30 & 2 & 6.7 & 21 & 15 & 71.4 \\
\hline $25-29$ & 169 & 7 & 4.1 & 73 & 29 & 39.7 \\
\hline $30-34$ & 376 & 14 & 3.7 & 192 & 46 & 24.0 \\
\hline $35-39$ & 525 & 48 & 9.1 & 314 & 75 & 23.9 \\
\hline $40-44$ & 472 & 66 & 14.0 & 366 & 122 & 33.3 \\
\hline $\begin{array}{l}45-49 \\
\text { Marital Status }\end{array}$ & 406 & 94 & 23.2 & 337 & 115 & 34.1 \\
\hline Married & 1595 & 171 & 10.7 & 973 & 264 & 27.1 \\
\hline Cohabiting & 117 & 16 & 13.7 & 125 & 52 & 41.6 \\
\hline Formerly Married & 223 & 32 & 14.3 & 149 & 54 & 36.2 \\
\hline $\begin{array}{l}\text { Unmarried } \\
\text { Education }\end{array}$ & 43 & 12 & 27.9 & 56 & 32 & 57.1 \\
\hline Elementary & 869 & 119 & 13.7 & 291 & 108 & 37.1 \\
\hline High School & 531 & 51 & 9.6 & 322 & 92 & 28.6 \\
\hline $\begin{array}{l}\text { Some College or } \\
\text { University }\end{array}$ & 577 & 60 & 10.4 & 692 & 203 & 29.3 \\
\hline Number of Child & & & & & & \\
\hline None & 113 & 38 & 33.6 & 93 & 63 & 67.7 \\
\hline One & 184 & 26 & 14.1 & 142 & 72 & 50.7 \\
\hline Two or More & 1680 & 67 & 9.9 & 1069 & 267 & 25.0 \\
\hline
\end{tabular}

Sources: Canadian Fertility Survey, 1985 and General Social Survey, 1995. 
Vijaya Krishnan and Kelly Martin

Sterilization patterns by religion and religious attendance are shown in Table 3a through Table 3c, for the two surveys. As the data in Table 3a, 3b, and 3c indicate, in 1995 as in 1984, there were no marked differences in the use of irreversible contraceptive procedures by religion or church attendance.

Almost universally, cultural patterns appear to regulate nuptiality and fertility behaviors. There are reasons to assume that these factors also link individuals into social networks that play a role in regulating fertility intentions and behaviors. In Canada, it is a consistent finding that sociodemographic phenomena change monotonically as one moves from the East to the West (Krishnan \&Krotki, 1999). English-French dualism has been noted as the most distinctive feature of the Canadian population for centuries.

Somewhat surprisingly, differences in levels of contraceptive sterilization were relatively small between the regions, with Ontarians reporting slightly greater use of tubal ligation than their counterparts in other provinces (not shown). Overall, in 1995, British Columbians reported greater use of sterilization than their counterparts in other provinces, despite the fact that they had the lowest rate of use in 1984 (not shown). In general then, the monotonic principle is ruled out in the case of sterilization status of women.

\section{Discussion and Conclusion}

Today, four out of every ten women of reproductive age practice sterilization in Canada. It appears that Canadians are confronted with a national epidemic of sterilization. Tubal ligations were far more common than vasectomies or hysterectomies in the country. The trend in recent years has shown a rapid decline in the number of tubal ligations, with a corresponding increase in the number of vasectomies and hysterectomies. In the 1970s and 1980s, there were concerns about vasectomy and arteriosclerosis. The safety of vasectomy was seriously doubted, and some specific health risks, such as prostate cancer were reported in those who had undergone the procedure (Sandlow \& Kreder, 1996; United States, 1996). By contrast, a study by Bemal-Delgado, Latour-Perez, Pradas-Amal, \& Gomez-Lopez (1998), found no association between the two. While we know little about the etiology of prostate cancer and thereby the causal relationship between vasectomy and prostate cancer, such findings might have contributed to an increase in male contraception. However, vasectomy still remains controversial. One of the primary aspects of the present study is the high incidence of formerly married women who reported relying on tubal ligation. On the other hand, the unmarried outnumbered others in their use of hysterectomies. Contraception, and in particular, sterilization appears to be more 
Table 3A

Number and Percentages of Tubal Ligations by Religious Characteristics of Women Age 18-49 Years in Two National Surveys for Canada: 1984 and 1995

\begin{tabular}{|c|c|c|c|c|c|c|}
\hline \multirow[b]{2}{*}{ Characteristics } & \multicolumn{3}{|c|}{ CFS 1984} & \multicolumn{3}{|c|}{ GSS 1995} \\
\hline & $\begin{array}{l}\text { number } \\
\text { of women }\end{array}$ & $\begin{array}{r}\text { tubal } \\
\text { number }\end{array}$ & $\begin{array}{l}\text { ations } \\
\text { percent }\end{array}$ & $\begin{array}{l}\text { number } \\
\text { of women }\end{array}$ & $\begin{array}{r}\text { tubal } \\
\text { number }\end{array}$ & $\begin{array}{l}\text { zations } \\
\text { percent }\end{array}$ \\
\hline \multicolumn{7}{|l|}{ Religion } \\
\hline Catholic & 925 & 599.0 & 64.8 & 634 & 251 & 39.6 \\
\hline Non-Catholic & 921 & 601.0 & 65.3 & 483 & 219 & 45.3 \\
\hline No Religion & 132 & 85.0 & 64.4 & 187 & 88 & 47.1 \\
\hline \multicolumn{7}{|l|}{ Religious Attendance } \\
\hline Rarely/Never & 679 & 443.0 & 65.2 & 608 & 266 & 43.8 \\
\hline Sometimes & 727 & 476.0 & 65.5 & 418 & 176 & 42.1 \\
\hline Weekly & 570 & 365.0 & 64 & 278 & 116 & 41.7 \\
\hline
\end{tabular}

Sources: Canadian Fertility Survey, 1985 and General Social Survey, 1995

of a health issue than a social issue. What determines one's method choice? Is the choice determined primarily by personal preferences, the availability of various methods, technology or the physicians themselves? Sterilization is not the leading cause of ill health or of death in the Canadian population. However, its frequency is such that it can have ramifications beyond mere health complications. Today, sterilizations can be performed without hospitalization through safe procedures, such as laparoscopy. However, as the epidemic is felt, the health care authorities and the government will have to face the realities and assess some of the physical, emotional, and health consequences of sterilization. Sterilization is a good example of the process of medicalization by which more and more aspects of our life are being brought into the medical sphere. It raises more questions than answers. Why is medicine involved and why is there a strong aptitude toward sterilization even in those countries with low levels of fertility? Not much is known about the dynamics of sterilization and the issues associated with it. Needless to say, the outbreak of sterilization, has implications beyond the borders of Canada. 
Table 3B

Number and Percentages of Partners' Vasectomies by Religious Characteristics of Women Age 18-49 Years in Two National Surveys for Canada: 1984 and 1995

\begin{tabular}{|c|c|c|c|c|c|c|}
\hline \multirow{3}{*}{ Characteristics } & \multicolumn{3}{|c|}{ CFS 1984} & \multicolumn{3}{|c|}{ GSS 1995} \\
\hline & number & tubal 1 & rations & number & tubal 1 & ations \\
\hline & of women & number & percent & of women & number & percent \\
\hline \multicolumn{7}{|l|}{ Religion } \\
\hline Catholic & 925 & 210 & 22.7 & 634 & 1073 & 26.8 \\
\hline Non-Catholic & 921 & 217 & 23.6 & 483 & $355^{*}$ & 25.5 \\
\hline No Religion & 132 & 35 & 26.5 & 187 & 453 & 26.7 \\
\hline \multicolumn{7}{|l|}{ Religious Attendance } \\
\hline Rarely/Never & 679 & 163 & 24.0 & 608 & 138 & 24.7 \\
\hline Sometimes & 727 & 176 & 24.2 & 418 & 1027 & 27.5 \\
\hline Weekly & 570 & 123 & 21.6 & 278 & 3449 & 28.1 \\
\hline
\end{tabular}

Sources: Canadian Fertility Survey, 1985 and General Social Survey, 1995

It is difficult to assess a high level of reported use of irreversible methods among young women. Sexual behavior is too complex, and it cannot be explained in terms of just social or biological factors. Another difficulty lies in the fact that descriptive studies have their own limitations. In other words, these findings need to be verified with multivariate techniques. In view of these findings, we can say that we have a situation in Canada where the practice of irreversible methods of contraception is spread laterally and vertically across various age, marital status, and educational categories. 
Table 3C

Number and Percentages of Hysterectomies by Religious Characteristics of Women Age 18-49 Years in Two National Surveys for Canada: 1984 and 1995

\begin{tabular}{|c|c|c|c|c|c|c|}
\hline \multirow[b]{2}{*}{ Characteristics } & \multicolumn{3}{|c|}{ CFS 1984} & \multicolumn{3}{|c|}{ GSS 1995} \\
\hline & $\begin{array}{l}\text { number } \\
\text { of women }\end{array}$ & $\begin{array}{r}\text { tubal } \\
\text { number }\end{array}$ & $\begin{array}{l}\text { percent } \\
\text { perions }\end{array}$ & $\begin{array}{l}\text { number } \\
\text { of women }\end{array}$ & $\begin{array}{l}\text { tubal li } \\
\text { number }\end{array}$ & $\begin{array}{l}\text { ations } \\
\text { percent }\end{array}$ \\
\hline \multicolumn{7}{|l|}{ Religion } \\
\hline Catholic & 925 & 116 & 12.5 & 634 & 213 & 33.6 \\
\hline Non-Catholic & 921 & 103 & 11.2 & 483 & 141 & 29.2 \\
\hline No Religion & 132 & 12 & 9.1 & 187 & 49 & 26.2 \\
\hline \multicolumn{7}{|l|}{ Religious Attendance } \\
\hline Rarely/Never & 679 & 163 & 24.0 & 608 & 192 & 31.6 \\
\hline Sometimes & 727 & 176 & 24.2 & 418 & 127 & 30.4 \\
\hline Weekly & 570 & 123 & 21.6 & 278 & 84 & 30.2 \\
\hline
\end{tabular}

Sources: Canadian Fertility Survey, 1985 and General Social Survey, 1995

\section{Acknowledgements:}

An earlier version of this kpaper was presented at the $31^{\text {st }}$ annual meeting of the British Sociological Association, Medical Sociology Group, University of York, York, UK, September 24-26, 1999.

\section{References:}

Belanger, A. (1998). "Trends in contraceptive sterilization," Social Trends (Autumn), 16-19.

Bemal-Delgado, E. Latour-Perez, J., Pradas-Amal, F., \& Gomez-Lopez, L. I. (1998). "The association between vasectomy and prostate cancer: A systematic review of the literature," Fertility and Sterility, 70(2): 191200. 
Vijaya Krishnan and Kelly Martin

Forste, R., Tanfer, K., \& Tedrow, L. (1995). "Sterilization among currently married men in the United States, 1991," Family Planning Perspectives, 27(3): 100-106.

Gentile, G. P., Kaufman, S. C., \& Helbig, D. W. (1998). "Is there any evidence for a post-tubal sterilization syndrome?" Fertility and Sterility, 69 (2): 179-86.

Goldberg, H. I. \& Toros, A. (1994). "The use of traditional methods of contraception among Turkish couples," Studies in Family Planning, 25(2): 122-128.

Krishnan, V. \& Krotki, K. J. (1999). "Impact of abortion on Canadian fertility trends," Canadian Studies in Population, 26(1): 67-81.

Krotki, K. J. (1988). The history and methodology of the Canadian Fertility Survey of 1984. In J. Legare, T. R. Balakrishnan, \& R. P. Beaujot (Eds.), The Family in Crisis: A Population Crisis. Ottawa: The Royal Society of Canada.

Mauldin, W. P. \& Segal, S. J. (1988). "Prevalence of contraceptive use: Trends and issues," Studies in Family Planning, 19(6): 335-353.

McLaren, A. \& McLaren, A. T. (1986). The Bedroom and the State: The Changing Practices and Politics of Contraception and Abortion in Canada, 1880-1980. Toronto: McClelland and Stewart.

Miller, W. B., Shain, R. N., \& Pasta, D. J. (1989). The sterilization decision in a U. S. sample. In R. A. Bulatao, J. A. Palmore, \& S. E. Ward (Eds.), Choosing a Contraceptive: Method Choice in Asia and the United States. East-West Center, Honolulu: Westview Press.

Murphy, M. (1995). "Sterilization as a method of contraception: Recent trends in Great Britain and their implications," Journal of Biosocial Science, 27: 31-46.

Nett, E. M. (1993). Canadian Families: Past and Present ( ${ }^{\text {nd }}$ edition). Toronto: Butterworths.

Peterson, H. B. \& Howards, S. S. (1998). "Vasectomy and prostate cancer: The evidence to date," Fertility and Sterility, 70(2): 201-203.

Poma, P.A. (1980). "Tubal sterilizations and later hospitalizations," Journal of Reproductive Medicine, 25: 272-278. 
Riphagen, P. E. \& Lehert, P. (1989). "A survey of contraception in five west European countries," Journal of Biosocial Science, 21: 23-46.

Sandlow, J. I. \& Kreder, K. J. (1996). "A change in practice: Current urologic practice in response to reports concerning vasectomy and prostate cancer," Fertility and Sterility, 66: 281-284.

Shy, K . K, Stergachis, S., Grothaus, L. G., Wagner, E. H., Hecht, J., \& Anderson, G. (1992). "Tubal sterilization and risk of subsequent hospital admission for menstrual disorders," American Journal of Obstetrics and Gynecology, 166: 1698-1706.

Skolnick, A. \& Skolnick, J. (1999). Family in Transition, 1997. In J. M. Charon (Ed.), The Meaning of Sociology: A Reader (pp. 300-307). New Jersey: Prentice Hall.

Statistics Canada (2002). "Trends in Canadian and American Fertility," The Daily, July 3.

United Nations (1999). Fertility and Contraception Globally. New York: United Nations.

United States (1996). Screening for Prostate Cancer in the US. :Guide to Clinical Preventive Services ( ${ }^{\text {nd }}$ edition). Preventive Services Task Force, Baltimore: Williams \& Wilkins.

Wilcox, L. S., Chu, S. Y., Eaker, E. D., Zeger, S. L., \& Peterson, H. B. (1991). "Risk factors for regret after tubal sterilization: 5 years of follow-up in a prospective study," Fertility and Sterility, 55: 927-933.

Wilcox, L. S., Martinez-Schnell, B., Peterson, H. B., Ware, J. H., \& Hughes, J. M. (1992). "Menstrual function after tubal sterilization," American Journal of Epidemiology, 135: 1368-81. 